\title{
Improvement of Pitting Corrosion Resistance of Type 430 Stainless Steel by Electrochemical Treatments in a Concentrated Nitric Acid
}

\author{
Sri HASTUTY, ${ }^{1) *}$ Eiji TADA $^{2)}$ Atsushi NISHIKATA, ${ }^{2)}$ Yusuke TSUTSUMI' ${ }^{3)}$ and Takao HANAWA ${ }^{3)}$ \\ 1) Department of Metallurgy and Ceramics Science, Tokyo Institute of Technology, 2-12-1 Ookayama, Meguro-ku, Tokyo, 152- \\ 8550 Japan. $\quad 2)$ Department of Chemistry and Materials Science, Tokyo Institute of Technology, 2-12-1 Ookayama, \\ Meguro-ku, Tokyo, 152-8550 Japan. 3 3) Institute of Biomaterials and Bioengineering, Tokyo Medical and Dental \\ University, 2-3-10 Kanda-Surugada, Chiyoda-ku, Tokyo, 101-0062 Japan.
}

(Received on May 24, 2013; accepted on September 13, 2013)

\begin{abstract}
Electrochemical surface treatments have been attempted in $5 \mathrm{kmol} / \mathrm{m}^{3} \mathrm{HNO}_{3}$ solution to improve pitting corrosion resistance of Type 430 stainless steel. Three different surface treatments were carried out for the same time period $(2.9 \mathrm{~h})$ under conditions of immersion, potentiostatic polarization at $0.9 \mathrm{~V} \mathrm{Vs}$. Ag/ $\mathrm{AgCl} / \mathrm{sat} . \mathrm{KCl}$ reference electrode $(\mathrm{E}=+0.222 \mathrm{~V}$ vs. SHE) and potential cycling between 0.6 and $0.9 \mathrm{~V}$. The pitting corrosion resistance was evaluated by an ordinary pitting potential measurement and droplet tests which simulates atmospheric corrosion in marine environments. It was found that the potential cycling treatment is most effective among them to improve pitting corrosion resistance. The surface analysis by EPMA and XPS indicated that the potential cycling most successfully removes MnS inclusions and increases $\mathrm{Cr}$ content in the passive film.
\end{abstract}

KEY WORDS: passive film; MnS inclusions; pitting corrosion; stainless steel; potential cycling polarization; nitric acid.

\section{Introduction}

The development of high corrosion resistant stainless steel (SS) with adequate reliability is an indispensable factor for ensuring the safety and economical operation of power plants, reducing maintenance cost of harbor and other infrastructure expose in marine atmospheric environment. One of the most severe and destructive types of localized attack is pitting corrosion, especially on ferritic SS due to its low nickel content.

However, ferritic SS is being promoted to be used more widely owing to their moderate corrosion resistance and affordable cost. Similar trend was also reported by U.S Geological Survey, ${ }^{1)}$ engineers have been encouraged to substituting low-nickel stainless steels for austenitic grades in construction applications in order to offset high and fluctuating nickel prices. Nickel-free specialty steels are sometimes used in place of stainless steel within the powergenerating and petrochemical industries. Another report explained ferritic stainless steel has the characteristics that it does not include $\mathrm{Ni}$, which is a problem due to metal allergies, and tends not to cause stress corrosion cracking, and so on. ${ }^{2)}$ So, it is clearly shown that ferritic stainless steel has a great potential to be explored.

* Corresponding author: E-mail: sri.hastuty@yahoo.co.id DOI: http://dx.doi.org/10.2355/isijinternational.54.199
An extensive number of researches have been performed on the origin of pitting corrosion. It has been hypothesized that pitting corrosion is caused by aggressive species in solution, ${ }^{3)}$ dissolution of inclusions due to low $\mathrm{pH}^{4)} \mathrm{Cr}$ :Fe oxide film alteration, ${ }^{5-7)}$ oxide film thickening or thinning, ${ }^{8)}$ or surface/oxide contamination from sulfur or other species. $^{9-11,13)}$ It has been well reported that localized corrosion initiates in stainless steels at inclusions, in particular, $\mathrm{MnS}$ inclusions. ${ }^{9,10,12,14-33)}$ Many mechanisms of pit initiation at $\mathrm{Mn}(\mathrm{Fe}, \mathrm{Cr}) \mathrm{S}$ inclusions have been proposed, but the basic mechanism is that either the inclusion begins to dissolve or the matrix around the inclusion dissolves, leading to the acid pitting mechanism. The low $\mathrm{pH}$ causes preferential dissolution of $\mathrm{Mn}(\mathrm{Fe}, \mathrm{Cr}) \mathrm{S}$ inclusions, releasing sulfur species that are known to cause damage to oxide films by suppressing repassivation, as well as by initiating further $\mathrm{Mn}(\mathrm{Fe}, \mathrm{Cr}) \mathrm{S}$ inclusion dissolution..$^{9,11,13,34)}$

Analyzing the potential of wider uses of ferritic SS in one hand and pitting corrosion's threat to deteriorating the steel in another hand, led to an idea to increase the ferritic SS pitting corrosion resistance by surface passivation; in concentrated nitric acid is one of the options. The use of nitric acid as a cleaning and passivating reagent of stainless steels is commonly employed in industry. The strong oxidizing conditions favour the formation of a passive film on the parts, which led to the use of the term "passivation" to describe the above treatment. Passive film forms spontaneously on 
stainless steels upon contact with air or with an electrolyte containing a sufficient amount of dissolved oxygen, so the purpose of prior immersion in $\mathrm{HNO}_{3}$ solutions is to form a protective passive film and to remove the $\mathrm{MnS}$ inclusions from the surface. ${ }^{6)} \mathrm{MnS}$ inclusions have been well known as a preferential site of pitting. Therefore, in order to increase the pitting resistance, the formation of a denser passive film and $\mathrm{MnS}$ inclusions removal is necessary. For this purpose, 20-40 vol\% $\mathrm{HNO}_{3}(3-6 \mathrm{M})$ solutions are often used at temperatures ranging from $c a .20$ to $c a .70^{\circ} \mathrm{C}$. J. S. Noh et $a l .{ }^{5)}$ suggested that the use of $20-25$ vol\% of $\mathrm{HNO}_{3}(3-4 \mathrm{M})$ has the most beneficial effect on improving pitting resistance. In addition, N. Padhy et al. ${ }^{35)}$ analyzed the effect of nitric acid concentration on 304L SS ranging from 1 to $11.5 \mathrm{kmol} / \mathrm{m}^{3}$ and the results showed that the good passive film stability in $1 \mathrm{kmol} / \mathrm{m}^{3}$ and $4 \mathrm{kmol} / \mathrm{m}^{3}$ nitric acid. In 8 and $11.5 \mathrm{kmol} / \mathrm{m}^{3}$ nitric acid, breakdown of passive film was observed, and the surface was stained with corrosion product.

Another number of research groups also have done extensive research on the similar field. Barbosa ${ }^{6)}$ investigated the pitting resistance of AISI 316 SS after passivation in diluted nitric acid and resulted an increasing of pitting potential under open circuit conditions in aerated sea water. It was suggested that immersion in the nitric acid solution was found to remove the sulphide inclusions from the metal surface. Similar results were also found by Noh et al. ${ }^{5)}$

There were a small number of publications on improvement of pitting corrosion resistance by the polarization methods. Ziad Bou-Saleh et al. ${ }^{36)}$ found that simple cyclic linear potentiodynamic polarization technique as a method of improving corrosion properties of passive films formed on a biomedical-grade 316LVM surface in phosphate buffer. The results demonstrated that the modification between the potential of hydrogen and oxygen evolution results in the formation of a passive film that offers significantly increased corrosion resistance (both pitting and general) when compared to the naturally grown passive film. The increasing of cycle number and anodic potential limit improved corrosion resistance. Another research group investigated the formation of passive film by potential square-wave polarization in hot sulfuric acid bath and they succeed to produce a thick passive film. ${ }^{37,38)}$ These studies open more possibility to enhance the passive film properties by different type of electrochemical method. Accordingly, this research has aims to look for a method to increase pitting corrosion resistance of type $430 \mathrm{SS}$ for marine atmospheric application by removal of $\mathrm{MnS}$ inclusions from surface safely and without leaving large pits behind will be investigated as well as formation of protective passive film.

\section{Experimental}

\subsection{Materials and Specimens}

Type $430 \mathrm{SS}$ sheets were cut into $15 \times 15 \mathrm{~mm}$ and then underwent to electrodeposition coating employing an organic resin, which was cured at $150^{\circ} \mathrm{C}$ for at least $1200 \mathrm{~s}$. This coating procedure was done in order to reduce the occurrence of crevice corrosion at the edge of the specimens. They were embedded in epoxy resin to give a two-dimensional surface and were ground with 1000 grit before experiment.
A conventional three electrode setup was employed, consisting of platinum counter electrode, a $\mathrm{Ag} / \mathrm{AgCl} / \mathrm{sat} . \mathrm{KCl}$ reference electrode (SSC) and a working electrode of the stainless steel. The composition of the stainless steel is given in Table 1.

\subsection{Surface Treatments}

In order to reduce $\mathrm{MnS}$ inclusions on $430 \mathrm{SS}$ surface, the surface treatment was carried out in an aerated $5 \mathrm{kmol} / \mathrm{m}^{3}$ $\mathrm{HNO}_{3}$ solution $(32 \% \mathrm{vol})$ by three different methods; (1) immersion, (2) potentiostatic polarization and (3) potential cycling. For the immersion treatment, the specimen was just submerged for $2.9 \mathrm{~h}$ in the solution. During the treatment, the corrosion potential change was measured to confirm the passivation process. The potentiostatic treatment was performed by polarizing the specimen at $0.9 \mathrm{~V}$ for $2.9 \mathrm{~h}$. In order to dissolve more inclusions, the applied potential has been raised up to $0.9 \mathrm{~V}$, right before onset potential of transpassive region. In Fig. 1, anodic polarization curve of $430 \mathrm{SS}$ in $5 \mathrm{kmol} / \mathrm{m}^{3} \mathrm{HNO}_{3}$ solution at $25^{\circ} \mathrm{C}$ is shown. It can be seen that the transpassive dissolution of $430 \mathrm{SS}$ starts above about $1.0 \mathrm{~V}$ in this solution. The potential cycling treatment was carried out by cyclic potential scans in the passive region between 0.6 and $0.9 \mathrm{~V}$. The same result was plotted in $\log$ of $\mathrm{Y}$-axis. The potential was positively scanned from 0.6 to $0.9 \mathrm{~V}$ at $10 \mathrm{mV} / \mathrm{s}$ and was quickly reversed to $0.6 \mathrm{~V}$ to reduce the treatment time. The potential cycling was carried out 350 times for $2.9 \mathrm{~h}$. All electrochemical measurement was done at $25^{\circ} \mathrm{C}$, unless otherwise noted.

\subsection{Pitting Corrosion Tests}

The pitting resistance was evaluated by two different droplet tests. ${ }^{39-41)}$ In their droplet tests, a droplet of $100 \mu \mathrm{L}$ of $1 \mathrm{kmol} / \mathrm{m}^{3} \mathrm{MgCl}_{2}$ was placed on the sample surface at $25^{\circ} \mathrm{C}$ in a relative humidity $(\mathrm{RH})$ programmable chamber. In the droplet test (I), the RH was step-wisely lowered from 95 , 80, 75, 65, 55, 45 and 35\%, as shown in Fig. 2. The exposure time at each RH was 4 days, where water molecule in

Table 1. Chemical composition of Type 430 SS.

\begin{tabular}{ccccccccc}
\hline Element & $\mathrm{C}$ & $\mathrm{Si}$ & $\mathrm{P}$ & $\mathrm{S}$ & $\mathrm{Mn}$ & $\mathrm{Ni}$ & $\mathrm{Cr}$ & $\mathrm{Fe}$ \\
\hline Mass\% & 0.081 & 0.52 & 0.033 & 0.006 & 0.31 & 0.12 & 16.2 & Bal. \\
\hline
\end{tabular}

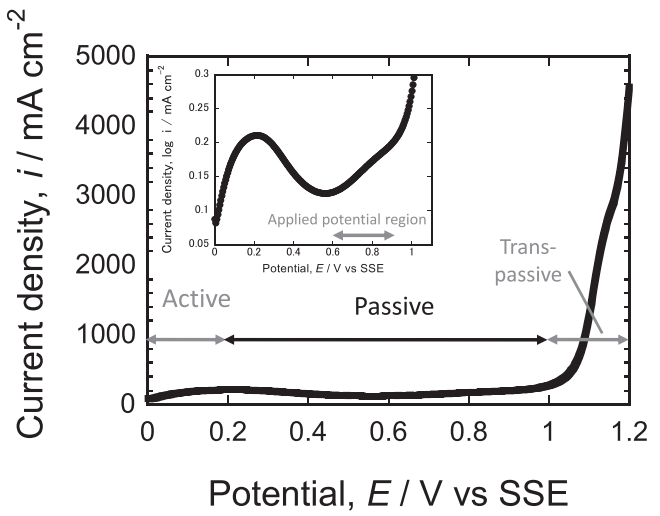

Fig. 1. Anodic polarization curve of Type 430 stainless steel in $5 \mathrm{kmol} / \mathrm{m}^{3} \mathrm{HNO}_{3}$ solution at $25^{\circ} \mathrm{C}$ recorded at scan rate of $10 \mathrm{mV} / \mathrm{s}$. 


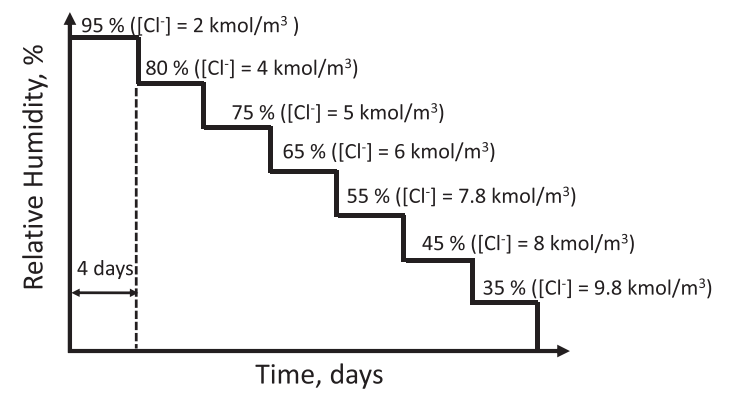

Fig. 2. Change of relative humidity in the droplet test (I). The RH was stepwisely dropped from 95 to $35 \%$ at at $25^{\circ} \mathrm{C}$. The $\left[\mathrm{Cl}^{-}\right]$indicates the equilibrium chloride concentration of the chloride solution droplets at each RH.

the droplet was in equilibrium with water vapor in the air. ${ }^{39,40)}$ The equilibrium chloride concentrations at respective RHs are shown in Fig. 2. ${ }^{39)}$ At the end of each RH, the surface was observed to check the pitting corrosion occurrence. In the droplet test (II), a droplet of $100 \mu \mathrm{L}$ of $0.5 \mathrm{kmol} / \mathrm{m}^{3} \mathrm{NaCl}$ solution was placed on the specimen surface. The sample was exposed to the wet-dry cycles shown in Fig. 3. To confirm the results of the droplet tests, the pitting potential $\left(E_{\mathrm{pit}}\right)$ was determined from anodic polarization curve measured at $10 \mathrm{mV} / \mathrm{s}$ in $0.5 \mathrm{kmol} / \mathrm{m}^{3} \mathrm{NaCl}$ solution at $25^{\circ} \mathrm{C}$. The experimental setup was similar with that of the surface treatment.

\subsection{Surface Characterization}

Distribution of MnS inclusions on 430 SS surface before and after the surface treatments was investigated by a Scanning Electron Microscope (SEM) with Electron Probe Micro Analysis (EPMA). After the surface treatments, the specimens were cleaned in acetone and sonicated for $15 \mathrm{~min}$ and then dried up with $\mathrm{N}_{2}$ gas. The passive film was characterized with X-ray Photoelectron Spectrometer (XPS, JEOL JPS-9010MC). All binding energies given in this paper are relative to the Fermi level, and all spectra were excited with the Al K $\alpha$ line (1 $486.61 \mathrm{eV})$. The used current and voltage for X-ray source were $10 \mathrm{~mA}$ and $10 \mathrm{kV}$, respectively. The binding energies were calibrated using the peak energy of C $1 \mathrm{~s}$ of contaminant carbon, $285.0 \mathrm{eV}$. The takeoff angle defined as the angle between the direction of the photoelectron path to the electron spectrometer and the specimen surface was $90^{\circ}$. XPS measurement was performed with 2 modes; wide scan for qualitative analysis and narrow scan for a detailed measurement of each element of the major peak. It could distinguish the electron binding state of the component, whether as metal or as oxide and also calculating the quantitative analysis for the oxide film.

\section{Results and Discussion}

\subsection{Surface Treatments}

The change in the rest potential $E_{\text {rest }}$ of $430 \mathrm{SS}$ in $5 \mathrm{kmol} / \mathrm{m}^{3}$ $\mathrm{HNO}_{3}$ solution is shown in Fig. 4. The $E_{\text {rest }}$ shifts gradually in positive direction approximately from 0 to $0.15 \mathrm{~V}$ at $2.9 \mathrm{~h}$. This indicates passivation progresses under the immersion treatment. Since it continues to shift positively, the passive film is still growing at $2.9 \mathrm{~h}$. Noh et al. ${ }^{5)}$ reported that for $304 \mathrm{SS}, \mathrm{MnS}$ dissolution occurs around $0.2 \mathrm{~V}$ with respect

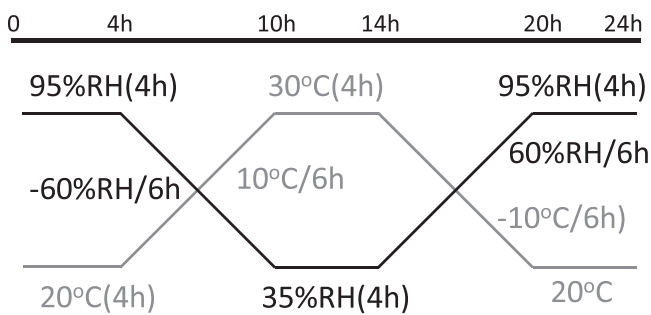

Fig. 3. Change of relative humidity $(\mathrm{RH})$ and temperature $(\mathrm{T})$ in the droplet test (II). The RH and T were cycled to simulate actual atmospheric environment. ${ }^{42)}$

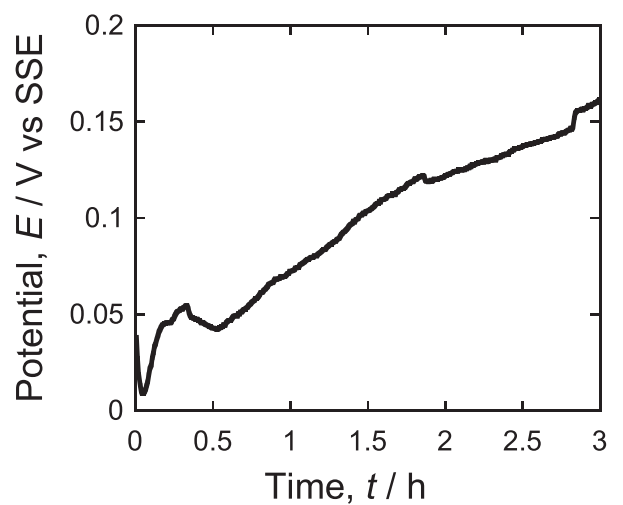

Fig. 4. Change in rest potential of Type 430 stainless steel with time in $5 \mathrm{kmol} / \mathrm{m}^{3} \mathrm{HNO}_{3}$ solution at $25^{\circ} \mathrm{C}$.

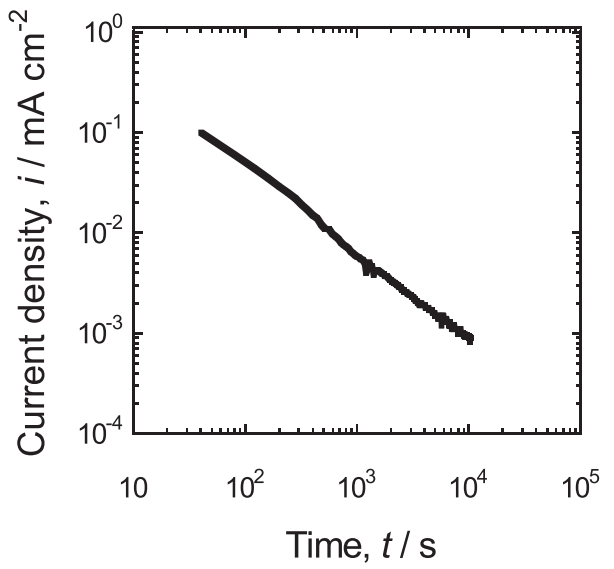

Fig. 5. Potentiostatic polarization of Type 430 stainless steel at $0.9 \mathrm{~V}$ in $5 \mathrm{kmol} / \mathrm{m}^{3} \mathrm{HNO}_{3}$ solution at $25^{\circ} \mathrm{C}$

to $\operatorname{SCE}(\mathrm{E}=+0.244 \mathrm{~V}$ vs. SHE) in $20 \mathrm{vol} \%$ of nitric acid (approximately $3 \mathrm{kmol} / \mathrm{m}^{3}$ ). Thus, $2.9 \mathrm{~h}$-immersion treatment employed in this study may not be sufficient to remove $\mathrm{MnS}$ inclusions.

Figure 5 shows a log-log plot of current density vs. time when $430 \mathrm{SS}$ is potentiostatically polarized at $0.9 \mathrm{~V}$ in $5 \mathrm{kmol} / \mathrm{m}^{3} \mathrm{HNO}_{3}$ solution. The current density continues to decrease with a slope $(\partial \log i / \partial \log t)$ of -1 until at least $2.9 \mathrm{~h}$. It indicates that the surface is quickly covered with a passive film and the growth is slow down with time, but continues at a negligibly small rate even at $2.9 \mathrm{~h}$. In addition, some $\mathrm{MnS}$ inclusions also may have dissolved out electrochemically. ${ }^{5,18)}$

A typical result of the potential cycling treatment in $5 \mathrm{kmol} / \mathrm{m}^{3} \mathrm{HNO}_{3}$ solution at $25^{\circ} \mathrm{C}$ is shown in Figs. 6(a)6 (b) and 7(a)-7(b) where only anodic scans from 0.6 to 

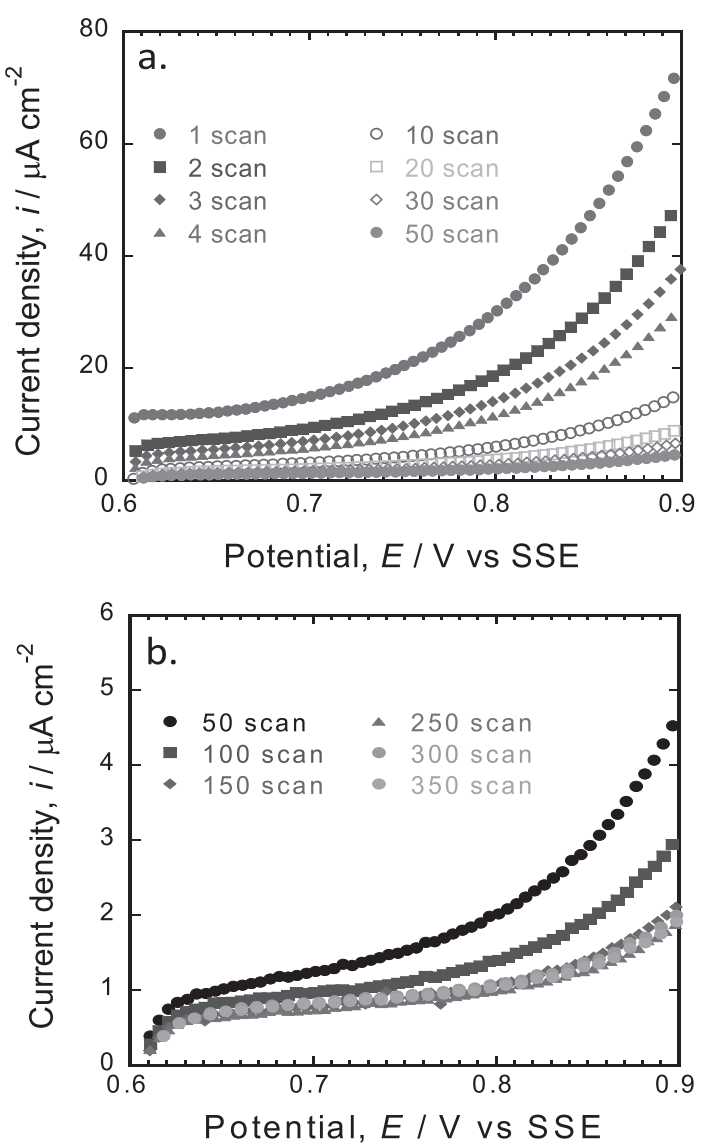

Fig. 6. Repetitive potential cycling curves of Type 430 stainless steel in $5 \mathrm{kmol} / \mathrm{m}^{3} \mathrm{HNO}_{3}$ solution at $25^{\circ} \mathrm{C}$ (a) $1-50$ scans and (b) 50-350 scans.
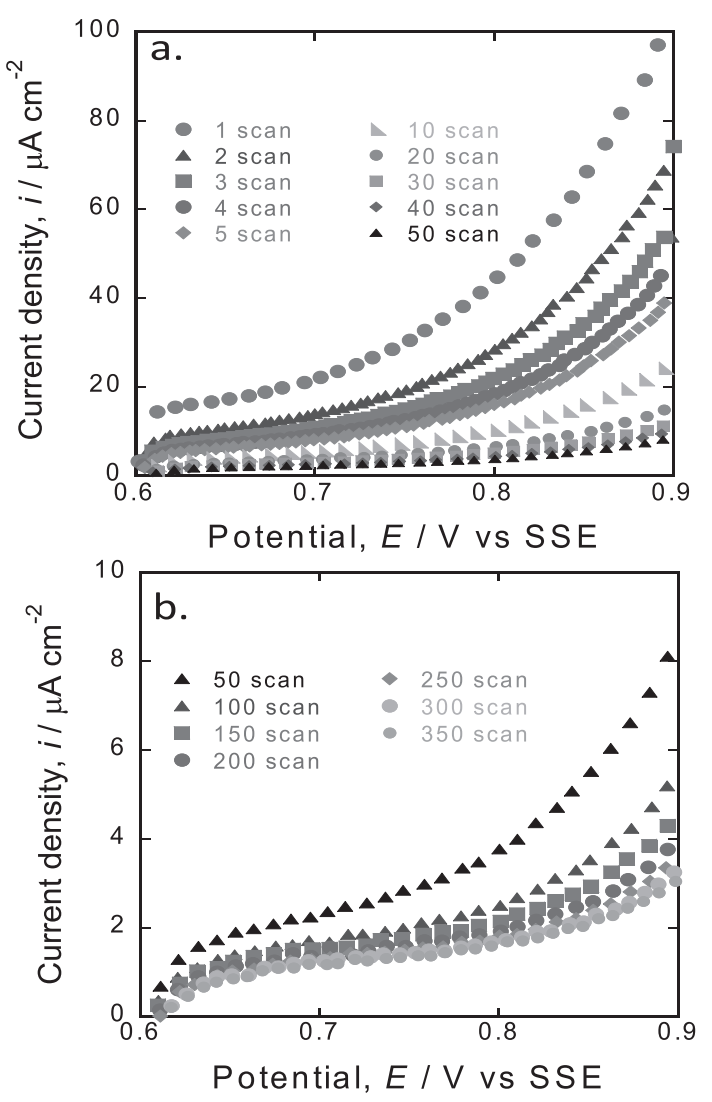

Fig. 7. Repetitive potential cycling curves of Type 430 stainless steel in $5 \mathrm{kmol} / \mathrm{m}^{3} \mathrm{HNO}_{3}$ solution at $50^{\circ} \mathrm{C}$ (a) $1-50$ scans and (b) 50-350 scans.

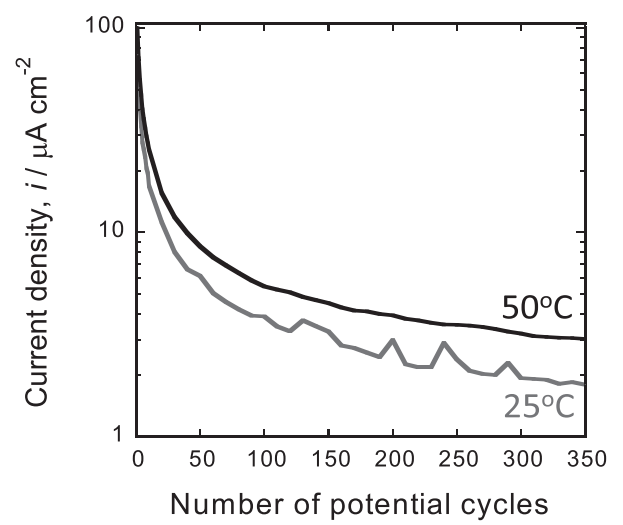

Fig. 8. Plots of current density at $0.9 \mathrm{~V}$ with respect to number of potential scan at 25 and $50^{\circ} \mathrm{C}$.

$0.9 \mathrm{~V}$ are presented. The cathodic scans from 0.9 to $0.6 \mathrm{~V}$ were not recorded because the potential was quickly reversed to reduce the time period of the surface treatment. On the first scan, the current density increases significantly with potential. This current is mainly due to the formation of passive films and anodic dissolution of the constituent metals. It may include current for dissolution of MnS. On the following scans, the magnitude of current density decreases and becomes lowered after 20 scans and does not much change until 350 scans. The magnitude of current density at $0.9 \mathrm{~V}$ of each scan at 25 and $50^{\circ} \mathrm{C}$ was summarized and shown in Fig. 8. Potential cycling at $50^{\circ} \mathrm{C}$ is slightly higher than that at $25^{\circ} \mathrm{C}$ from the first until the last scan (350). This discrepancy may have some contributions on the improvement of pitting corrosion of ferritic SS.

\subsection{Evaluation of Pitting Corrosion Resistance}

The pitting resistance was evaluated by the droplet tests. The results of the droplet test (I) shown in Fig. 2 are shown in Table 2. The RH and chloride concentration shown is the critical value of pitting occurrence. For example, pitting occurred at $80 \% \mathrm{RH}\left(\left[\mathrm{Cl}^{-}\right]=4 \mathrm{kmol} / \mathrm{m}^{3}\right)$ for the as-polished sample. Above $80 \% \mathrm{RH}$ (below $4 \mathrm{kmol} / \mathrm{m}^{3}\left[\mathrm{Cl}^{-}\right]$), no pitting occurred even it was exposed for $100 \mathrm{~h}$ because the surface was completely passivated, ${ }^{41)}$ but at $80 \% \mathrm{RH}$ or below $\left(4 \mathrm{kmol} / \mathrm{m}^{3}\left[\mathrm{Cl}^{-}\right]\right.$or above), pitting would occurred.

As-polished sample suffered from pitting at $80 \% \mathrm{RH}$ $\left(\left[\mathrm{Cl}^{-}\right]=4 \mathrm{kmol} / \mathrm{m}^{3}\right)$ and the immersion and potentiostatictreated samples at $65 \% \mathrm{RH}\left(\left[\mathrm{Cl}^{-}\right]=6 \mathrm{kmol} / \mathrm{m}^{3}\right)$. The immersion and potentiostatic treated samples have slightly better pitting corrosion resistance than non-treated sample. A higher pitting corrosion resistance was obtained by the potential cycling of 350 scans which has a critical $\mathrm{RH}_{\text {critical }}$ and $\left[\mathrm{Cl}^{-}\right]_{\text {critical }}$ of $35 \%$ and $9.8 \mathrm{kmol} / \mathrm{m}^{3}$, respectively. The passivated surface could be kept from $4 \mathrm{kmol} / \mathrm{m}^{3}\left[\mathrm{Cl}^{-}\right]$to $6 \mathrm{kmol} / \mathrm{m}^{3}$ by the immersion and potentiostatic treatments and then to $9.8 \mathrm{kmol} / \mathrm{m}^{3}$ by the potential cycling. It was reported in the previous study that the $\left[\mathrm{Cl}^{-}\right]_{\text {critical }}$ and $\mathrm{RH}_{\text {critical }}$ for Type 304 SS are $6 \mathrm{kmol} / \mathrm{m}^{3}$ and $65 \%$ under the droplet test, respectively. ${ }^{39)}$ The pitting corrosion resistance of $430 \mathrm{SS}$ treated by the immersion and potentiostatic is equal with that of 304 SS. Furthermore, higher pitting corrosion resistance is expected by the potential cycling treatment.

However, in the droplet test (II) shown in Fig. 3, which may be a severer corrosion condition that the droplet test (I), 
Table 2. Critical relative humidity $[\mathrm{RH}]_{\text {critical }}$ and chloride concentration $\left[\mathrm{Cl}^{-}\right]_{\text {critical }}$ for occurrence of pitting corrosion of the surface-treated samples in the droplet test (I) at $25^{\circ} \mathrm{C}$.

\begin{tabular}{|c|c|c|c|c|}
\hline & As-polished & $\begin{array}{l}\text { Immersion } \\
\text { at } 25^{\circ} \mathrm{C}\end{array}$ & $\begin{array}{c}\text { Potentiostatic } \\
\text { at } 25^{\circ} \mathrm{C}\end{array}$ & $\begin{array}{c}\text { Potential cycling } \\
\text { at } 25^{\circ} \mathrm{C}\end{array}$ \\
\hline$[\mathrm{RH}]_{\text {critical }} / \%$ & 80 & 65 & 65 & No pit \\
\hline$\left[\mathrm{Cl}^{-}\right]_{\text {critical }} / \mathrm{kmol} / \mathrm{m}^{3}$ & 4 & 6 & 6 & No pit \\
\hline
\end{tabular}

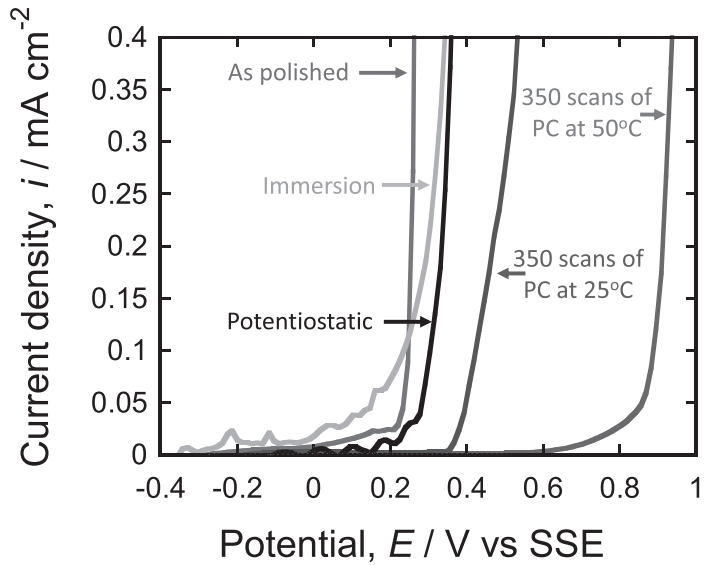

Fig. 9. Anodic polarization curves in $0.5 \mathrm{kmol} / \mathrm{m}^{3} \mathrm{NaCl}$ solution before and after surface treatments.

the sample treated by the potential cycling at $25^{\circ} \mathrm{C}$ could not stand from pitting after 1 cycle. A very good result was given by the sample of the potential cycling at $50^{\circ} \mathrm{C}$. It did not suffer pitting after 4 cycles of wet and dry environment. Therefore, the potential cycling treatment at higher temperature is more effective.

Pitting corrosion potential $E_{\text {pit }}$ was measured in $0.5 \mathrm{kmol} / \mathrm{m}^{3}$ $\mathrm{NaCl}$ solution at $25^{\circ} \mathrm{C}$ to confirm the results of the droplet tests. The results are shown in Fig. 9. The criteria to determine pitting corrosion potential is when the current has reached $100 \mu \mathrm{A} / \mathrm{cm}^{2}$. The $E_{\text {pit }}$ values of the as-polished and immersion treatment are quite similar, around $0.25 \mathrm{~V}$. The pitting corrosion resistance after the surface treatment increased from 0.30 to 0.45 of potentiostatic and 350 potential scans at $25^{\circ} \mathrm{C}$, respectively. A very high pitting corrosion resistance was achieved by the potential cycling at $50^{\circ} \mathrm{C}$. The $E_{\text {pit }}$ was $0.90 \mathrm{~V}$ which is just below the transpassive dissolution potential. The results of $E_{\text {pit }}$ measurements show good consistency with the droplet tests.

\subsection{Surface Examination}

SEM image of the treated 430 SS sample surface by the 350 potential cycling at $25^{\circ} \mathrm{C}$ is shown in Fig. 10. The micro pits with about $2 \mu \mathrm{m}$ diameters were found on the surface which is the actual size of $\mathrm{MnS}$ inclusion. It is thought that the surface treatment removes the MnS inclusions successfully without dissolution of the substrate. Probably, the substrate quickly passivates just after $\mathrm{MnS}$ dissolution in nitric acid solution, unlike in chloride solutions. Elemental mappings in Fig. 11 showed the MnS inclusions at higher magnification. $\mathrm{Fe}$ and $\mathrm{Cr}$ are not incorporating with $\mathrm{Mn}$ and $\mathrm{S}$, so the surrounding of $\mathrm{MnS}$ inclusion is not covered by protective chromium-enriched, leaving it exposed defenselessly to the corrosive environment.

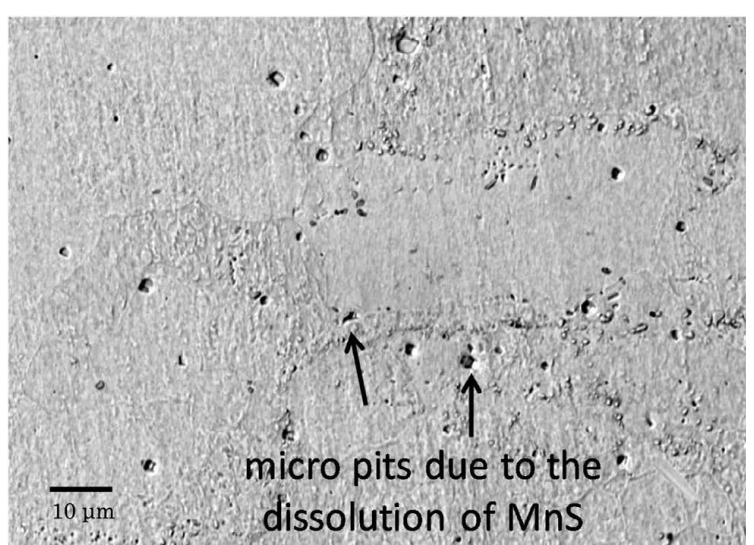

Fig. 10. SEM Image of micro pits after 350 potential cycles between $0.6-0.9 \mathrm{~V}$ in $5 \mathrm{kmol} / \mathrm{m}^{3} \mathrm{HNO}_{3}$ solution at $25^{\circ} \mathrm{C}$.

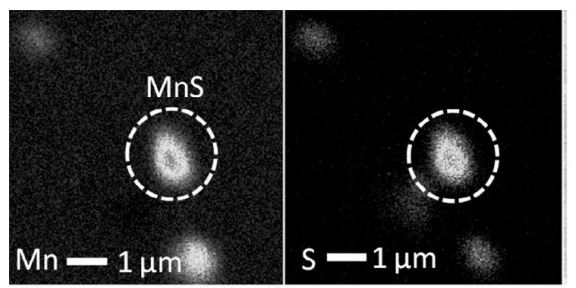

Intensity charts

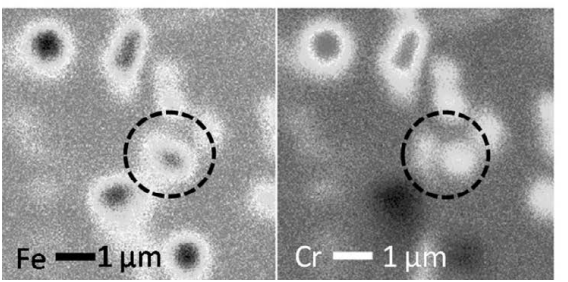

Fig. 11. SEM image and elemental mapping, a.as-polished, b. 350 potential cycles at $25^{\circ} \mathrm{C}$, c. 350 potential cycles at $50^{\circ} \mathrm{C}$.

In Fig. 12 shows the distribution of $\mathrm{MnS}$ inclusions. The number of $\mathrm{MnS}$ inclusions was much reduced by surface treatment. The number of potentiodynamic scan also affect on reducing the inclusions. More scans would dissolve more inclusions which means the preferential site of pitting is removed. The square dotted line (Fig. 12(b)) is a cluster of micro pits and its contains very little amount of Fe, but contains high concentration of $\mathrm{Cr}$. This $\mathrm{Cr}$ enrichment enable pit to repassivate and inhibits the growth of the micro pit even during polarization in $\mathrm{NaCl}$ and droplet test either in equilibrium and wet-dry cycle environment. A small amount of Fe was dissolved out along with $\mathrm{MnS}$ inclusion. Accordingly, pitting resistance of $430 \mathrm{SS}$ increased due to the removal of initiation sites of pitting, MnS inclusions and chromium enrichment. $^{6,43)}$

Figure $12(\mathrm{c})$ is the mapping of elements after surface treatment 350 cycles of $\mathrm{PC}$ at $50^{\circ} \mathrm{C}$. Chromium covers larger area which is thought to be chromium carbide. ${ }^{44)}$ Some undissolved $\mathrm{MnS}$ inclusions were also still remained, even though their size (around 1-2 $\mu \mathrm{m}$ ) has exceeded the critical value of $\mathrm{MnS}$ inclusion to cause pitting. ${ }^{33,45)}$ Probably because their location are adjacent to chromium carbide, so hindered the inclusion dissolution, even in extreme condition; wet-dry cycles. In other area, a small micro pit was found, that covered by $\mathrm{Cr}$.

In Fig. 13, the ratio of $\mathrm{Cr}$ to $\mathrm{Fe}$ in the passive film obtained by X-Ray Photoelectron Spectroscopy (XPS) is 
a.
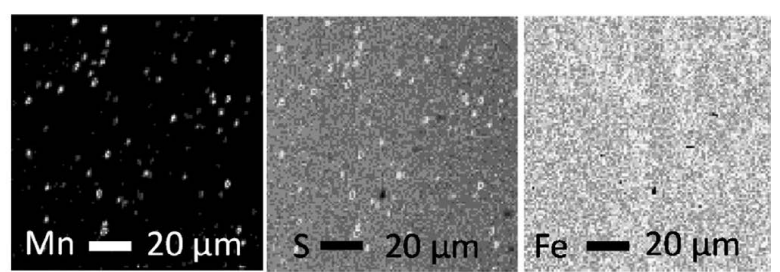

Intensity charts

b.

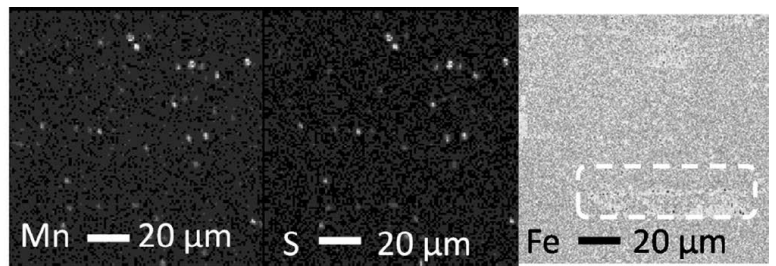

c.
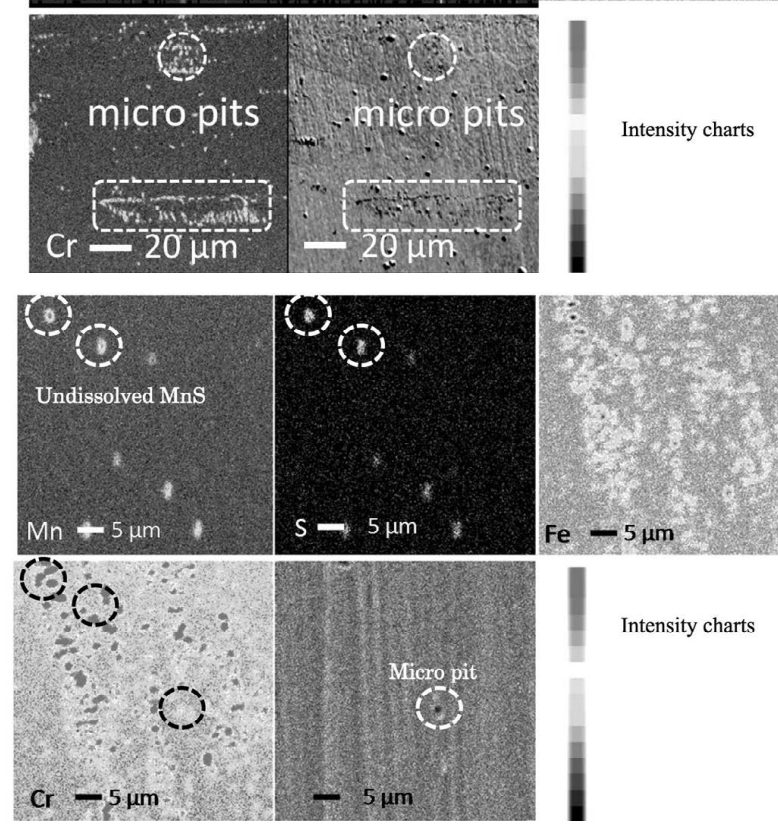

$\mathrm{Fe}-5 \mu \mathrm{m}$

Intensity charts

Fig. 12. SEM image of MnS inclusions on as-polished sample surface.

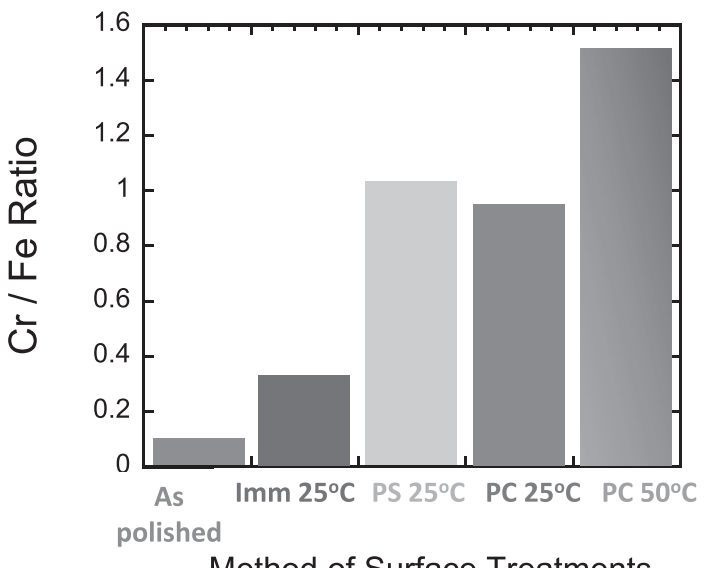

Method of Surface Treatments

Fig. 13. $\mathrm{Cr} / \mathrm{Fe}$ ratio in passive film by $\mathrm{X}$-Ray Photoelectron Spectroscopy (XPS). presented. The $\mathrm{Cr} / \mathrm{Fe}$ ratio was 0.1 for the as-polished sample, 0.35 for the immersion treatment, 1.0 for the potentiostatic, 0.8 for the potential cycling at $25^{\circ} \mathrm{C}$ and 1.5 for the potential cycling at $50^{\circ} \mathrm{C}$. The XPS study indicates the pretreatments improve the passive film, especially the potential cycling at $50^{\circ} \mathrm{C}$

\subsection{Mechanism of the Pitting Resistance Improvement by Potential Cycling}

The difference in the pitting corrosion resistance of $430 \mathrm{SS}$ by different pretreatments; immersion, potentiostatic and potential cycling in concentrated nitric acid are discussed below.

Figure 14(a) is the schematics of $\mathrm{MnS}$ dissolution and passive film formation by the immersion treatment in concentrated nitric acid. Once the surface is exposed to the air, the air-formed passive film is formed on the surface. The $\mathrm{MnS}$ inclusions are distributed on the surface and less-protective passive film covers them because the MnS inclusions contain less Cr. Therefore, they become the weak point and pitting takes place preferentially at the inclusion sites. After the immersion in $5 \mathrm{kmol} / \mathrm{m}^{3} \mathrm{HNO}_{3}$ solution, the air-formed passive film turns to stable passive film in this solution. The $\mathrm{Cr} / \mathrm{Fe}$ ratio of the passive film increases from 0.1 to 0.35 by XPS analysis. The MnS inclusions might not be electrochemically dissolved out from the report by $\mathrm{Noh}^{5)}$ in which $\mathrm{MnS}$ dissolution in 20-25 vol\% $\mathrm{HNO}_{3}$ took place around $0.30-0.40 \mathrm{~V}$ vs SCE, although they might dissolve chemically ${ }^{14)}$ according to the reaction;

$$
\mathrm{MnS}+2 \mathrm{H}^{+} \rightarrow \mathrm{Mn}^{2+}+\mathrm{H}_{2} \mathrm{~S}
$$

In Figs. 14(b)-14(c), the schematic of MnS dissolution and passive film formation under the conditions of the potentiostatic and potential cycling are displayed. In the initial stage, some inclusions dissolve out due to applied anodic potential. MnS inclusions are argued to decompose electrochemically at high potentials. ${ }^{18)}$

$$
2 \mathrm{MnS}+3 \mathrm{H}_{2} \mathrm{O} \rightarrow 2 \mathrm{Mn}^{2+}+\mathrm{S}_{2} \mathrm{O}_{3}^{2-}+6 \mathrm{H}^{+}+8 e^{-}
$$$$
\mathrm{MnS}+2 \mathrm{H}^{+} \rightarrow \mathrm{Mn}^{2+}+\mathrm{S}+\mathrm{H}_{2}
$$

The reactions above will occur in the anodic polarization, the remaining inclusions on the surface will be covered by a very thin passive film, which thought have different composition with that one formed on the substrate of SS. Finally, under the potentiostatic polarization at $0.9 \mathrm{~V}$, the condition of the surface is similar with that of surface at the initial stage. The passive films consist of $\mathrm{Cr}$ and $\mathrm{Fe}$ in a balance composition, around 1 .

The difference between the potentiostatic and potential cycling is the application of cathodic potential change in potential cycling. It takes place in very short time from 0.9 to $0.6 \mathrm{~V}$; however the reduction of passive film thickness could occur, ${ }^{46,47)}$ including the thin film that covered the inclusions, which might give opportunities for $\mathrm{MnS}$ to be dissolved out in the subsequent anodic scan. As a result more $\mathrm{MnS}$ inclusions are forced to remove from the surface, some by chemical dissolution and mostly by electrochemical. Running to the next scans, the same process will undergo. At last scan; 350, much thicker passive film with $\mathrm{Cr}$ enriched is formed stably on the surface and the number of 


\section{a. Immersion}

Initial stage

Formation of denser passive film on substrate and MnS surface

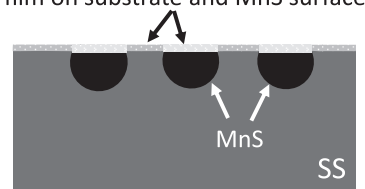

SS

\section{b. Potentiostatic}

Initial stage

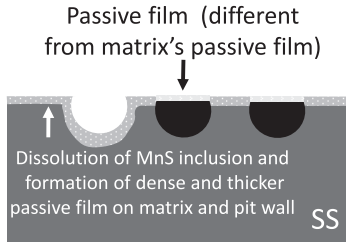

c. Potential Cycling

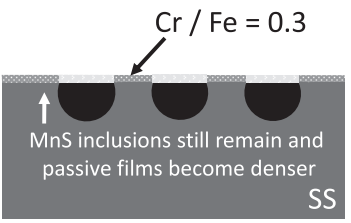

\section{Last stage}

Initial stage
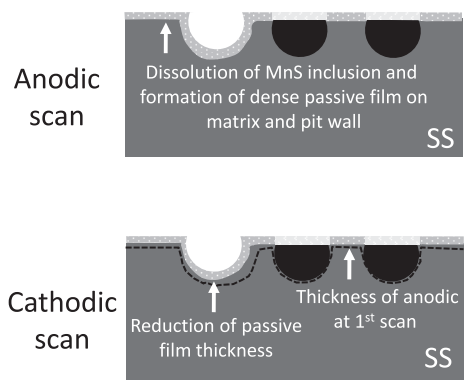

Last stage

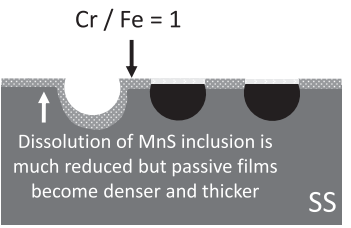

Fig. 14. Mechanism of $\mathrm{MnS}$ dissolution and passivation by the surface treatments of (a) immersion, (b) potentiostatic and (c) potential cycling in concentrated nitric acid.

MnS are much reduced. Even though the thickness of passive film a little suppressed in cathodic scan, the accumulative thickness of anodic scan is sufficient to protect the surface from further dissolution, even during the atmospheric droplet tests where extreme condition of chloride ions occurred. The final stage of passivation by potential cycling results a higher ratio of chromium on iron, 1.5 (Fig. 13).

\section{Conclusions}

From results obtained with type 430 stainless steel subjected to potential cycling surface treatments in concentrated nitric acid, the following conclusions are drawn.

(1) Micro pits with 1-2 $\mu \mathrm{m}$ diameters were found on the surface. Therefore, the employed method was successfully removed the inclusions and formed protective passive film.

(2) After surface treatment, it was found chromium enrichment inside pit that enable the pit to repassivate and resists its growth.

(3) Treated SUS 430 SS by potential cycling 350 scans at $50^{\circ} \mathrm{C}$ is suitable for applications in marine atmospheric environment as no pit propagates between 95 and 35\% relative humidity $\left(\left[\mathrm{Cl}^{-}\right]=2\right.$ and $9.8 \mathrm{kmol} / \mathrm{m}^{3}$, respectively).

\section{REFERENCES}

1) Mineral Commodity Summaries 2011, U.S Geological Survey, US Department of the Interior, Washington DC, (2011).

2) Material Outlook for Energy and Environment 2011, National Institute for Materials Science, Tsukuba, Ibaraki, Japan, (2011).

3) T. T. Lunt, J. R. Scully, V. Brusamarello, A. S. Mikhailov and J. L. Hudson: J. Electrochem. Soc., 149 (2002), B163.

4) B. Baroux: Corrosion Mechanisms in Theory and Practice, ed. by P. Marcus and J. Oudar, Marcel Dekker, New York, (1995), 265.

5) J. S. Noh, N. J. Laycock, W. Gao and D. B. Wells: Corros. Sci., 42 (2000), 2069.

6) M. A. Barbosa: Corros. Sci., 23 (1983), 1293.

7) M. P. Ryan, D. E. Williams, R. J. Chater, B. M. Hutton and D. S. McPhail, Nature, 415 (2002), 770.

8) K. Sugimoto, S. Matsuda, Y. Ogiwara and K. Kitamura: J. Electrochem. Soc., 132 (1985), 1791.

9) G. Eklund: Scand. J. Metall., 1 (1972), 331.

10) M. B. Ives and S. C. Srivastava: Corrosion, 43 (1987), 687.

11) P. Marcus and H. Talah: Corros. Sci., 29 (1989), 455.

12) J. Stewart and E. Williams: Corros. Sci., 33 (1990), 457.

13) M. A. Baker and J. E. Castle: Corros. Sci., 34 (1993), 667.

14) C. S. Brossia: Critical Factors in Localized Corrosion III, PV 98-17, ed. by R. G. Kelly, P. M. Natishan, G. S. Frankel and R. C. Newman, The Electrochemical Society Proc. Series, Pennington, NJ, (1998), 326.

15) G. Eklund: J. Electrochem. Soc., 121(1974), 467.

16) R. Ke and R. Alkire: J. Electrochem. Soc., 139 (1992), 1573

17) R. Ke and R. Alkire: J. Electrochem. Soc., 142 (1995), 4056.

18) E. Lott and R. C. Alkire: J. Electrochem. Soc., 136 (1989), 973.

19) A. M. Riley, D. B. Wells and D. E. Williams: Corros. Sci., 32 (1991), 1307.

20) A. J. Sedriks: Int. Met. Rev., 28 (1983), 295.

21) M. Smialowski, Z. Szklarska-Smialowska, M. Rychcik and A. Szummer: Corros. Sci., 9 (1969), 123.

22) Z. Szklarska-Smialowska: Corrosion (Houston), 28 (1972), 388.

$23)$ E. G. Webb and R. C. Alkire: J. Electrochem. Soc., 149 (2002), B272.

24) G. Wranglen: Corros. Sci., 14 (1974), 331.

25) N. J. E. Dowling, C. Duret-Thual, G. Auclair, J. P. Audouard and P. Combrade: Corrosion (Houston), 51 (1995), 343.

26) E. G. Webb and R. C. Alkire: J. Electrochem. Soc., 149 (2002), B280.

27) E. G. Webb and R. C. Alkire: J. Electrochem. Soc., 149 (2002), B286.

$28)$ E. G. Webb, C. H. Paik and R. C. Alkire: Electrochem. Solid-State Lett., 4 (2001), B15.

29) J. N. Harb and R. C. Alkire: J. Electrochem. Soc., 138 (1991), 2594.

30) A. Bond and E. A. Lizlovs: J. Electrochem. Soc., 115 (1968), 1130.

31) R. M. Kain: Corrosion 91, NACE Conf. and Corrosion Show, NACE International, Houston, USA, (1991).

32) C. H. Paik and R. C. Alkire: J. Electrochem. Soc., 148 (2001), B276.

33) T. Suter and H. Bohni: Electrochim. Acta, 42 (1997), 3275.

34) P. Marcus and H. Talah: Corros. Sci., 29 (1989), 455.

35) N. Padhy, R. Paul, U. K. Mudali and B. Raj: Appl. Surf. Sci., 257 (2011), 5088.

36) Z. Bou-Saleh: Thin Solid Film., 515 (2007), 4727.

37) S. Fujimoto, H. Nakatsu, S. Hata and T. Shibata: Corros. Sci., 38 (1996), No. 9, 1473.

38) S. Fujimoto, K. Tsujino and T. Shibata: Electrochim. Acta, 47 (2001), 543.

39) Y. Tsutsumi, A. Nishikata and T. Tsuru: Corros. Sci., 49 (2007), 1394.

40) Y. Tsutsumi, A. Nishikata and T. Tsuru: J. Electrochem. Soc., 152 (2005), No. 9, B358.

41) S. Hastuty, A. Nishikata and T. Tsuru: Corros. Sci., 52 (2010), 2035.

42) A. Tsutsumi, A. Nishikata and T. Tsuru: J. Electrochem. Soc., 153 (2006), No. 7, B278.

43) G. Okamoto and T. Shibata: Corros. Sci., 10 (1970), 371.

44) R. Tanaka: Selection and Usage of Stainless Steel, LSA, Japanese Standards Association, Tokyo, (2010), 104.

45) A. W. Gjønnes: Master Thesis, Norwegian University of Science and Technology, (2012).

46) V. Maurice, W. P. Yang and P. Marcus: J. Electrochem. Soc., 145 (1998), 909.

47) A. Machet, A. Galtayries, S. Zanna, L. Klein, V. Maurice, P. Jolivet, M. Foucault, P. Combrade, P. Scott and P. Marcus: Electochim. Acta, 49 (2004), 3957. 